\title{
Macroeconomic Conditions and Capital Structure over the Business Cycles: Further Evidence in the Context of Taiwan
}

\author{
Hsien-Hung H. Yeh ${ }^{*}$ \\ Department of Business Administration \\ National Pingtung University of Science and Technology \\ Nei-Pu, Pingtung 91207, Taiwan \\ Email: hhyeh@mail.npust.edu.tw \\ TEL: 88687703202 ext. 7685
}

FAX: 88687740367

and

Eduardo Roca

Department of Accounting, Finance and Economics

Griffith University

Nathan, Queensland 4111, Australia

Email: E.Roca@griffith.edu.au

TEL: +61 737357583

FAX: +61 737353719

\footnotetext{
* Corresponding author

The authors are grateful for the valuable comments and suggestions received from the anonymous referees and the Editor. We would also like to thank Professor Michael Drew, and Dr. Kurt Dew and Dr. Graham Bornholt of Griffith University for helpful comments. In addition, Yeh thanks the National Pingtung University of Science and Technology, Taiwan and the Griffith Business School of Griffith University, Australia for financial assistance provided.
} 


\section{Macroeconomic Conditions and Capital Structure over the Business Cycles: Further Evidence in the Context of Taiwan}

ABSTRACT: We examine the effect of macroeconomic conditions on capital structure of firms in the petrochemical, textile and electronics industries of Taiwan during the period 1983-2007 which covers six and a half business cycles. Controlling for the effects of economic growth, industry type and main firm-specific factors, we find that macroeconomic conditions have a significant effect on debt ratios during the sample period. Debt ratios of firms in these industries are pro-cyclical during the period before the 1997-1998 Asian financial crisis but counter-cyclical during the period after the Asian financial crisis.

KEY WORDS: capital structure, macroeconomic conditions, Taiwan. 


\section{Introduction}

Over the last several decades, there has been a voluminous amount of studies on capital structure. Focusing mainly on the effects of factors at the firm and industry levels, these studies have documented common determinants of capital structure (Harris and Raviv 1991). These prior studies have identified a number of firm-specific factors, namely firm size, growth opportunities, profitability, earning volatility, non-debt tax shields and asset tangibility that affect capital structure. However, some of these firm-level determinants of capital structure, for example profitability and growth opportunities, may vary with macroeconomic conditions over the business cycle. This suggests, therefore, that capital structure may vary with macroeconomic conditions.

Jensen's free cash flow theory (1986) contended that corporate debt financing enables managers to effectively bond their promise to pay out future cash flows. Thus, debt can reduce the agency cost of free cash flow because debt decreases the cash flow available for spending at the discretion of managers. Jensen asserted that the threat caused by failure to make debt service payments can serve as an effective motivating force to make organizations more efficient. Thus, based on Jensen's free cash flow theory, firms would finance more debt during economic expansion due to the increase in cash flow but less debt during economic contraction due to the decrease in cash flow. This implies that capital structure would be pro-cyclical over the business cycle. 
On the contrary, Miller (1977) found variation in the debt ratios of non-financial companies over the business cycles between the 1920s and the 1960s. He concluded that the cyclical movements of the economy result in lower debt ratios during economic expansion. Consistent with the finding of Miller (1977), Korajczyk and Levy (2003), with financial constraints taken into account, examined the effect of macroeconomic conditions on capital structure decisions and found a counter-cyclical or negative effect on corporate leverage ratios for financially unconstrained firms. Hackbarth, Miao and Morellec (2006) analyzed capital structure with credit risk under consideration in their model and contended that default thresholds are countercyclical and, thus, stated that market leverage ratios should be countercyclical. Levy and Hennessy (2007) analyzed corporate financing over business cycles in their general equilibrium model and contended that capital structure is counter-cyclical for the less constrained firms. It appears therefore that, theoretically, there is no agreement as to the effect of macroeconomic conditions on capital structure. Hence, in this paper, we gather further evidence on the effect of macroeconomic conditions on capital structure.

Further, Glen and Singh (2004) find that capital structure in emerging countries is different from that observed in developed countries. However, most evidence on the effect of macroeconomic conditions on capital structure come from developed countries rather than developing countries or emerging markets (Črnigoj and Mramor 2009; Hazak 
2009; Nieh, Yau and Liu 2008). For example, in the investigation of target capital structure of listed Taiwanese electronic firms, Nieh, Yau and Liu (2008) found a single threshold effect of debt ratio on return on equity that is used to proxy firm value. Nieh et al. also found that the optimal debt ratio range for electronic listed firms in Taiwan should not be over 51.57 percent or below 12.37 percent. Further, in a Slovenian empirical study, Črnigoj and Mramor (2009) concluded that, throughout the period 1999 to 2006, the financial behavior of Slovenian firms most probably remained different from those in mature market economies. In addition, they found that the financial behavior of Slovenian firms was changing during transition. Still further, Hazak (2009) analyzed corporate capital structure and dividend decisions under distributed profit taxation in Estonia. This study found that the distributed profit taxation system led Estonian firms to pay less dividends and retain more earnings and, in addition, the importance of external financing in total capital of the sample firms has decreased. These previous studies, however, did not take account of the effect of macroeconomic conditions on capital structure.

This paper, therefore, addresses this important gap in the literature through an examination of the effect of macroeconomic conditions on capital structure in the context of Taiwan with a focus on the textile, petrochemical and electronics industries. Taiwan is a country that has had a very successful experience of economic transition 
from being an emerging country to becoming a developed one. The country adopted a selective industry policy from the 1950 s to the 1990 s which is recognized to have played an important role in its economic development (Chu 1994, 2003). The textiles, petrochemical and electronic industries served as the corner stones of this industrial policy. As far as we know, no study examining the impact of macroeconomic conditions on these industries in the context of Taiwan has been conducted. In this paper, we investigate the effect of macroeconomic conditions on capital structure over the business cycles before and after the 1997-1998 Asian financial crisis in relation to the textiles, petrochemical and electronics industries of Taiwan. In particular, we seek to answer the following questions:

1. Did macroeconomic conditions affect capital structure for periods before and after the 1997-98 Asian financial crisis?

2. If so, did the effect of macroeconomic conditions on capital structure vary across periods before and after the Asian financial crisis?

The rest of the paper is organized as follows. Section 2 provides a literature review while Section 3 discusses the methods and data. The empirical results are presented in Section 4 and Section 5 concludes the study.

\section{Literature Review}


After the fundamental work of Modigliani and Miller (1958), extensive studies have been conducted on capital structure decisions, as summarized by Harris and Raviv (1991). These previous studies have addressed the issue at the firm and industry levels and have found common firm-specific determinants of capital structure, which include firm size, growth opportunities, profitability, non-debt tax shields and asset tangibility. Economic output falls during the period of recession but increases during the period of expansion, particularly at economic trough and peak. Some firm-specific determinants of capital structure, for example profitability and growth opportunities, may also vary with the state of economy over the business cycles as there are more future growth opportunities at economic trough but less growth opportunities at economic peak available to firms. The link between macroeconomic conditions, firm-level factors and capital structure therefore suggests that capital structure would be related to macroeconomic conditions.

Jensen's free cash flow theory (1986) asserted that debt can be used to motivate managers in making their organizations more efficient in the presence of large free cash flow. Jensen contended that debt creation enables managers to effectively bond their promise to pay out future cash flows and thus debt can be an effective substitute for dividend. Debt reduces the agency cost of free cash flow because it reduces the cash flow available for spending at the discretion of managers. The threat caused by failure to 
make debt service payments can serve as an effective motivating force to improve organizations' efficiency. Hence, to reduce the agency problem between management and shareholders in order to achieve organizational efficiency, firms would finance with more debt during economic expansion due to the increase in cash flow but with less debt during economic contraction due to the decrease in cash flow. This implies that capital structure would be pro-cyclical over the business cycle.

However, Miller (1977) reported that debt ratios of the typical non-financial companies varied with the business cycles between 1920 and 1960 and, in addition, debt ratios tended to fall during economic expansions. Korajczyk and Levy (2003) examined the impact of macroeconomic conditions on capital structure. They split their sample into two sub-samples, financially constrained and financially unconstrained, which allowed them to test whether the tradeoff theory and the pecking order theory can explain the effects of financial constraints and macroeconomic conditions on capital structure decisions. Korajczyk and Levy found that corporate leverage is countercyclical for financially unconstrained firms. Hackbarth et al. (2006) developed a contingency-claims model and analyzed credit risk and capital structure. They argued that shareholders' value-maximization default policy is characterized by different threshold for each state and, in addition, default thresholds are countercyclical. Their model predicted that market leverage should be countercyclical. Further, Levy and 
Hennessy (2007) developed a general equilibrium model for corporate financing over the business cycles. Levy and Hennessy argued that managers would hold a proportion of their firm's equity, i.e. managerial equity shares, in order to avoid agency conflicts. Firms finance with less debt due to the increases in managerial wealth and risk sharing during expansions than during contractions. Based on their simulations, Levy and Hennessy found a counter-cyclical variation in leverage for less constrained firms. Their finding of a negative effect of macroeconomic conditions on capital structure is consistent with Korajczyk and Levy (2003).

Based on the above discussion, it seems therefore that, theoretically, there is no agreement as to the effect of macroeconomic conditions on capital structure. Furthermore, Glen and Singh (2004) found that capital structure of firms in developed countries is different from that in emerging markets. However, most previous studies on the effect of macroeconomic conditions on capital structure were conducted within the context of developed countries rather than developing countries or emerging markets. Thus, this paper addresses this gap by providing further evidence on this issue in the context of Taiwan, a newly industrialized country at the beginning of this century. 


\section{Methods and Data}

\section{The Model for the Determination of Capital Structure}

As suggested by previous studies (Chen 2004; Chu, Wu and Chiou 1992; Feidakis and Rovolis 2007; Hackbarth, Miao and Morellec 2006; Harris and Raviv 1991; Korajczyk and Levy 2003; Kuo and Wang 2005), firm characteristics, industry type, economic growth and macroeconomic conditions are related to capital structure. Moreover, the findings in previous studies on the adjustment of capital structure (Flannery and Rangan 2006; Ozkan 2001; Qian, Tian and Wirjanto 2009) show that debt ratios are positively related to their lagged values in the adjustment process of capital structure although there is ongoing debate as to whether firms adjust toward the target or not (Chang and Dasgupta 2009; Hovakimian and Li 2011). Therefore, we assume that firm characteristics, industry type, economic growth and macroeconomic conditions and the previous level of capital structure linearly determine the capital structure of firms.

Taking account of macroeconomic conditions (EC) and economic growth (EG), industry type (IND), firm-specific factors including firm size (SIZE), growth opportunities (GROWTH), profitability (PROFIT), non-debt tax shields (NDTS) and asset tangibility (ASSET), and the previous level of capital structure $\left(\mathrm{CS}_{\mathrm{t}-1}\right)$, the model for the determination of capital structure (CS) can be written as follows: 


$$
\begin{aligned}
& \mathrm{CS}_{\mathrm{it}}=\beta_{0}+\beta_{\mathrm{EC}} \mathrm{EC}_{\mathrm{it}}+\beta_{\mathrm{EG}} \mathrm{EG}_{\mathrm{it}} \\
& +\beta_{I N D} \mathrm{IND}_{\mathrm{it}}+\beta_{1} \mathrm{SIZE}_{\mathrm{it}}+\beta_{2} \mathrm{GROWTH}_{\mathrm{it}}+\beta_{3} \text { PROFIT }_{\mathrm{it}} \\
& +\beta_{4} \mathrm{NDTS}_{\mathrm{it}}+\beta_{5} \mathrm{ASSET}_{\mathrm{it}}+\beta_{6} \mathrm{CS}_{\mathrm{it}-1}+\varepsilon_{\mathrm{it}}
\end{aligned}
$$

Based on Equation 1, the coefficient on the binary dummy variable EC, which represents macroeconomic conditions, is expected to be negative based on the finding of previous studies that macroeconomic conditions have a counter-cyclical effect on capital structure (Hackbarth, Miao and Morellec 2006; Korajczyk and Levy 2003; Levy and Hennessy 2007).

To further investigate whether the effect of macroeconomic conditions on capital structure varies across periods, we expand Equation 1 with extended specification by including the dummy proxy for periods before and after the 1997-98 Asian financial crisis, (AFC), and the product of the proxies for macroeconomic conditions and the Asian financial crisis , $(\mathrm{EC} \times \mathrm{AFC})$, as follows:

$$
\begin{aligned}
& \mathrm{CS}_{\mathrm{it}}=\beta_{0}+\beta_{\mathrm{EC}} \mathrm{EC}_{\mathrm{it}}+\beta_{\mathrm{AFC}} \mathrm{AFC}_{\mathrm{it}}+\beta_{\mathrm{EC} \times \mathrm{AFC}} \mathrm{EC} \times \mathrm{AFC}_{\mathrm{it}}+\beta_{\mathrm{EG}} \mathrm{EG}_{\mathrm{it}} \\
& +\beta_{I N D} \mathrm{IND}_{\mathrm{it}}+\beta_{1} \mathrm{SIZE}_{\mathrm{it}}+\beta_{2} \mathrm{GROWTH}_{\mathrm{it}}+\beta_{3} \mathrm{PROFIT}_{\mathrm{it}} \\
& +\beta_{4} \mathrm{NDTS}_{\mathrm{it}}+\beta_{5} \mathrm{ASSET}_{\mathrm{it}}+\beta_{6} \mathrm{CS}_{\mathrm{it}-1}+\varepsilon_{\mathrm{it}}
\end{aligned}
$$

\section{Variables and Measures}

As suggested by most of the previous studies (Chen 2004; Harris and Raviv 1991; Qian,

Tian and Wirjanto 2009), the ratio of total debts to total assets, i.e. debt ratio (DR), is used as the proxy for the capital structure of firms. To examine the effect of economic conditions on capital structure, the years during the periods from economic troughs to 
economic peaks and during the periods from economic peaks to economic troughs in the sample period of 1983 to 2007, are selected to represent economic expansion and contraction, respectively. The binary dummy variable EC with a value of 1 and 0 for economic expansion and contraction, respectively, is used as the proxy for the shift in macroeconomic conditions. The classification of economic expansion and contraction is based on the reference dates of business cycles in the Taiwan Business Indicators that are officially published by the Council for Economic Planning and Development of Taiwan (CEPD 2009).

Moreover, the binary dummy AFC, with values of 0 and 1 , is used to denote the period before and after the 1997-98 Asian financial crisis, respectively while the annual growth rate of gross domestic production (gGDP) is used as the proxy for economic growth (Feidakis and Rovolis 2007). Bradley, Jarrell and Kim (1984) found a significant difference in firm leverage ratios. Among the twenty-five selected industries in their sample, the mean debt ratios for the electronics, petroleum-refining and textile industries were $16 \%, 24 \%$ and $33 \%$, respectively. Their finding suggests that firms in the electronics industry tend to finance with less debt than those in the petrochemical and textile industries. In our study, the binary dummies IND13 and IND14 denote the petrochemical and textile industries, respectively, if they have a value of 1 , and the electronics industry when their value is 0 . The natural logarithm of total assets $(\ln \mathrm{TA})$ is 
used to measure firm size (Chen 2004; Kuo and Wang 2005) and the annual growth rate of total assets (gTA) proxies for growth opportunities. Profitability is represented by the ratio of operating income to total assets (OITA) (Titman and Wessels 1988). The ratio of total depreciation to total assets (DEPTA) is used as the proxy for non-debt tax shields (Chen 2004; Chu, Wu and Chiou 1992; Kim and Sorensen 1986; Qian, Tian and Wirjanto 2009; Titman and Wessels 1988; Wald 1999; Wiwattanakantang 1999). The ratio of inventory plus net fixed assets to total assets (INVFATA) is used to measure collateral value or tangibility of asset structure (Chen 2004; Chu, Wu and Chiou 1992; Downs 1993; Titman and Wessels 1988; Wald 1999).

\section{Estimation}

Due to the presence of the one-period lagged dependent variable as a regressor in our dynamic panel data model, the lagged dependent variable in the equation is correlated with the error term. The ordinary least squares (OLS) estimator is therefore biased and inconsistent. Further, the instrumental variable estimation method can lead to the estimator being consistent but not necessarily efficient in the dynamic panel model. This is partly because the differenced structure in the disturbances is not considered in the instrumental variable estimation method (Baltagi 2008). With instrumental variables taken into account in the specification of a dynamic panel model, the generalized 
method of moments (GMM) estimation can lead to consistent and efficient estimates of parameters (Baltagi 2008).

However, the standard GMM robust two-step estimator of the variance-covariance matrix (VCE) can be seriously biased. Windmeijer (2005) found from his Monte Carlo studies that estimated standard errors of the efficient two-step generalized method of moments (GMM) estimator can be severely biased downward in small samples. He derived a bias-corrected robust estimator, i.e. WC-robust estimator, for two-step VCEs from GMM estimators, which are robust to heteroskedasticity in the errors. Thus, in this study we use the two-step dynamic panel-data GMM (DPD-GMM) estimation that can be implemented in the linear dynamic panel-data estimation (i.e. XTDPD) of Stata. Instrumental variables that are used in our DPD-GMM estimation include macroeconomic conditions, economic growth, industry type, firm-specific variables and the lagged dependent variable. More detailed information in relation to the DPD-GMM estimation can be found in the Stata User's Guide (StataCorp 2009).

\section{Sample and Data}

The sample includes the listed firms in the petro-chemical, textile and electronics industries of Taiwan that have complete financial data during the period 1983-2007 over six and a half business cycles. Annual financial data of firms in the selected 
industries are collected from the database of the Taiwan Economic Journal. However, firms that experienced financial distress or trade suspension are excluded. The sample consists of 137 listed firms in the selected industries over the research period. In the sample, there are 16 firms from the petrochemical, 48 from the textile and 73 from the electronics industries. In total, there are 2,718 observations in the sample over the period of 1983-2007 of which, 1,485 observations pertain to the period 1983-1998 which covers four business cycles and 1,233 observations relate to the period of 19992007 which encompasses two and half business cycles after the 1997-1998 Asian financial crisis. Unbalanced panel data are used in the study to examine the effect of macroeconomic conditions on capital structure across periods before and after the Asian financial crisis of 1997-1998.

\section{Descriptive Statistics and Correlation Matrix}

Table 1 provides a summary descriptive statistics of the variables in the study. As can be seen in Panel A of Table 1, the average debt ratio of firms in the sample industries for the full sample period 1983-2007 is about 40.85 percent. For the sub-periods, 1983-1998 (pre-financial crisis) and 1999-2007 (post-financial crisis), the average debt ratio for the firms is $42.59 \%$ and $38.76 \%$, respectively, as can be seen in Panels B and C of the table. This shows that the average debt ratio for firms in the three industries 
seems to decline after the financial crisis.

\section{[INSERT TABLE 1 HERE]}

The correlation matrix among debt ratios, economic variables and firm-specific variables is presented in Table 2. As shown in the table, the binary dummy proxy for macroeconomic conditions (EC) is not significantly related to debt ratios (DR) of firms in the selected industries. This indicates that macroeconomic conditions seem to be not related to the debt ratios of firms in the selected industries during the period 19832007. The proxy for economic growth (gGDP) is significantly and positively related to the debt ratios. The dummy IND13, the proxy for the petrochemical industry, is statistically significant and negatively related to the debt ratios; however, the dummy IND14, which proxies for the textile industry, is not significantly related to the debt ratios. These results suggest that the debt ratios of firms may vary across these three industries during the period of 1983-2007. Moreover, all of the proxies for firm characteristics are significantly related to the debt ratios and the one-period lagged debt ratios (DRlag) are positively related to the debt ratios, which is in line with the finding of previous studies on the adjustment of capital structure. This confirms that it is appropriate for us to include the one-period lagged debt ratios in the model.

[INSERT TABLE 2 HERE] 


\section{Regression Results}

The two-step dynamic panel-data GMM regression results for the debt ratios of firms in the petrochemical, textile and electronics industries over the business cycles during the sub-periods 1983-1996, 1983-1998 and 1999-2007 are shown in Table 3. As shown in the table, the Arellano-Bond test performed with the XTDPD command of Stata suggests that it is appropriate for us to use the DPD-GMM estimation in this study because of the absence of second-order residual correlation. In addition, the Sargan test of over-identifying restrictions for instrumental variables in the DPD-GMM estimation indicates that over-identifying restrictions are valid. Moreover, the Wald test for testing the joint significance of independent variables suggests that the debt ratios are significantly influenced by one or more independent variables in the dynamic panel data model.

\section{[INSERT TABLE 3 HERE]}

Further, as can be seen in column A of Table 3, controlling for firm-specific and industry effect, macroeconomic conditions (EC) and economic growth (gGDP) are significantly and positively related to debt ratios (DR) of firms in these three selected industries for the period 1983-1996 (before the 1997-98 Asian financial crisis). Similar results are found for the period 1983-1998, as shown in column B of the table. These findings suggest that, controlling for the effect of economic growth as well as the 
firm-specific and industry effect, macroeconomic conditions have a positive effect on debt ratios of firms in the sample industries before the 1997-1998 Asian financial crisis. However, macroeconomic conditions are significantly and negatively related to debt ratios of firms in the sample industries during the same period. As a whole, the above findings suggest that the debt ratios of firms in the petro-chemical, textile and electronics industries of Taiwan vary across periods before and after the 1997-1998 Asian financial crisis.

Moreover, as shown in column $\mathrm{C}$ of Table 3, the proxy for economic growth (gGDP) is not significantly related to the debt ratios of firms in the sample industries for the period of 1997-2007 (after the 1997-1998 Asian financial crisis). It is possible that the debt ratios of firms in these industries may be affected by economic development or/and financial development of Taiwan (Akimov and Dollery 2008; Boyd and Smith 1996). In particular, Boyd and Smith (1996) concluded that the aggregate ratio of debt to equity will generally decline as an economy develops. Future research may provide evidence on the effect of economic and financial development on capital structure.

In addition, as shown in columns A and B of Table 3, the results show that the debt ratios in the petrochemical and textile industries are significantly lower than those in the electronics industry during the period before the Asian financial crisis. This finding is not in line with that of Bradley et al. (1984). It is likely that firms in the electronics 
industry finance more debt than those in the petrochemical and textile industries due to Taiwan's industrial policy in favor of the selective industry during the pre-financial crisis period. However, during the period after the Asian financial crisis, the debt ratios in the electronics industry are significantly higher than those in the textile industry. This is most probably because of the change in the government industrial policy, as mentioned earlier in the Introduction section. Future research may provide further evidence on the effect of industrial policy on capital structure decisions. Finally, as can be seen in the table, the results for the effect of firm characteristics on debt ratios are consistent with the findings of most previous studies.

Further regression results based on panel least square estimation are reported in Table 4 and 5. As can be seen in Table 4, for regression results that do not include the lagged debt ratios in the model, the Durbin-Watson d statistic is far from 2, which suggests that the estimator is biased and inconsistent due to serious residual autocorrelation.

\section{[INSERT TABLES 4 \& 5 HERE]}

On the other hand, as shown in the regression results presented in Table 5, when the lagged debt ratios are included in the model, the explanatory power is greater than when lagged debt ratios are excluded. However, the Lagrange multiplier (LM) test rejects the null hypothesis of no residual autocorrelation. This suggests that the panel 
least square estimation for the model with one-period lagged debt ratios cannot lead to efficient and consistent estimator because of residual autocorrelation.

To provide further evidence as to whether or not the effect of macroeconomic conditions on debt ratios varies across periods before and after the 1997-98 Asian financial crisis, we expand our model by including a dummy proxy for the 1997-98 Asian financial crisis (AFC) and the product of the proxies for macroeconomic conditions and the Asian financial crisis $(\mathrm{EC} \times \mathrm{AFC})$. For robustness check, the DPDGMM regression results for debt ratios at different periods are reported in Table 6.

\section{[INSERT TABLE 6 HERE]}

As can be seen in Table 6, the Arellano-Bond test for zero autocorrelation in firstdifferenced errors performed with the XTDPD command of Stata suggests that it is appropriate for us to use DPD-GMM estimation in this study. The Sargan test of overidentifying restrictions for instrumental variables in the DPD-GMM estimation indicates that over-identifying restrictions are valid. The Wald test for testing joint significance of independent variables suggests that the debt ratios are significantly influenced by one or more independent variables in the model for different periods of time. Moreover, as shown in Table 6, debt ratios in these three selected industries are significantly and positively related to the proxy for macroeconomic conditions (EC) over the business cycles for different periods of time, i.e. 1983-2007, 1985-2007, and 
1989-2007. This implies that macroeconomic conditions have a positive, pro-cyclical effect on debt ratios of firms in these three industries. The dummy proxy for the Asian financial crisis (AFC) is positively and statistically related to the debt ratios at different periods of time. This suggests that debt ratios in the selected industries have increased after the 1997-98 Asian financial crisis. However, the proxy for the interaction between macroeconomic conditions and the Asian financial crisis $(\mathrm{EC} \times \mathrm{AFC})$ has a significant, negative effect on the adjustment of debt ratios at different periods. As a whole, the results illustrate that the effect of macroeconomic conditions on debt ratios in these selected industries vary across the periods before and after the 1997-98 Asian financial crisis. This finding is consistent with those shown in Table 3.

\section{Conclusion}

Some recent studies on the effect of macroeconomic condition on capital structure suggested that capital structure is counter-cyclical over the business cycles. However, Jensen's free cash flow theory contended that debt can reduce the agency cost of free cash flow because debt reduces the cash flow available for spending at the discretion of managers and thus debt financing can serve as an effective motivating force to make organizations more efficient. Based on Jensen's free cash flow theory, firms would finance with more debt during economic expansion but with less debt during economic 
contraction due to the change in cash flow. This implies that capital structure would be pro-cyclical over the business cycle. Hence, it appears that there is no agreement as regards the effect of macroeconomic conditions on capital structure. In this study, we provided fresh additional evidence on this issue. We examined the effect of macroeconomic conditions on debt ratios of firms in the petrochemical, textile and electronics industries of Taiwan over the period of 1983-2007 that covers six and a half business cycles in Taiwan.

The results showed that the debt ratios of firms in these industries are significantly influenced by macroeconomic conditions. We found that the debt ratios for firms are pro-cyclical over the business cycles during the period of 1983-1996, i.e. before the 1997-98 Asian financial crisis, which supports Jensen's free cash flow theory. However, our results showed that debt ratios are counter-cyclical over the business cycles during the period 1999-2007, i.e. after the Asian financial crisis, which is in accord with the findings and conclusion of previous studies on the effect of macroeconomic conditions. Further, the results revealed that debt ratios have increased after the 1997-1998 Asian financial crisis. In addition, we found that the interaction between macroeconomic conditions and the Asian financial crisis has a significant, negative effect on debt ratios in these three industries. Future research may provide new insights into how financial crisis affects capital structure decisions. 
Further, we found that debt ratios vary across industries for periods before and after the 1997-1998 Asian financial crisis. Debt ratios of firms in the electronics industries are significantly higher than those in the petrochemical and textile industries during the period before the 1997-1998 Asian financial crisis. This finding is not in line with that of Bradley et al. in 1984. This is likely because of government industrial policy in favour of the selective industry during the 1980s and 1990s. However, due to the change in the selective industry policy by the Taiwanese government, the debt ratios of firms in the electronics industry are significantly higher only than those of the textile industry during the post-financial crisis period. Future research to gather further evidence as regards the effect of government industrial policy on capital structure is recommended. Finally, overall, our findings on the effect of firm characteristics on debt ratios in these three industries are consistent with those of most previous studies on capital structure. 


\section{References}

Akimov, A., and B. Dollery. 2008. "Financial System Reform in Kazakhstan from 1993 to 2006 and Its Socioeconomic Effects." Emerging Markets Finance and Trade 44, no. 3: 81-97.

Baltagi, B. H. 2008. Econometric Analysis of Panel Data. New York: John Wiely \& Sons.

Boyd, J., and B. Smith. 1996. "The Coevolution of the Real and Financial Sectors in the Growth Process." World Bank Economic Review 10, no. 2: 371-396.

Bradley, M.; G. A. Jarrell; and E. H. Kim. 1984. "On the Existence of an Optimal Capital Structure: Theory and Evidence." Journal of Finance 39, no. 3: 857878.

Chang, X., and S. Dasgupta. 2009. "Target Behavior and Financing: How Conclusive Is the Evidence?" Journal of Finance 64, no. 4: 1767-1796.

Chen, J. J. 2004. "Determinants of capital structure of Chinese-listed companies." Journal of Business Research 57, no. 12: 1341-1351.

Chu, P. Y.; S. Wu; and S. F. Chiou. 1992. "The Determinants of Corporate Capital Structure Choice: Taiwan Evidence." Journal of Management Science 9, no. 2: 159-177 [Text in Traditional Chinese].

Chu, W. 1994. "Import substitution and export-led growth: A study of Taiwan's 
petrochemical industry." World Development 22, no. 5: 781.

2003. Taiwan's Economy under Globalization. Taipei: Ton-San [Text in

Traditional Chinese].

Council for Economic Planning and Development (CEPD). 2009. Taiwan Business

Indicators. Taipei, Taiwan: CEPD

Črnigoj, M., and D. Mramor. 2009. "Determinants of Capital Structure in Emerging European Economies: Evidence from Slovenian Firms." Emerging Markets Finance and Trade 45, no. 1: 72-89.

Downs, T. W. 1993. "Corporate Leverage and Nondebt Tax Shields: Evidence on Crowding-Out." Financial Review 28, no. 4: 549-583.

Feidakis, A., and A. Rovolis. 2007. "Capital Structure Choice in European Union: Evidence from the Construction Industry." Applied Financial Economics 17, no. 12: $989-1002$.

Flannery, M. J., and K. P. Rangan. 2006. "Partial Adjustment toward Target Capital Structures." Journal of Financial Economics 79: 469-506.

Glen, J., and A. Singh. 2004. "Comparing Capital Structures and Rates of Return in Developed and Emerging Markets." Emerging Markets Review 5, no. 2: 161192.

Hackbarth, D.; J. Miao; and E. Morellec. 2006. "Capital Structure, Credit Risk, and 
Macroeconomic Conditions." Journal of Financial Economics 82: 519-550.

Harris, M., and A. Raviv. 1991. "The Theory of Capital Structure." Journal of Finance 46, no. 1: 297-355.

Hazak, A. 2009. "Companies' Financial Decisions Under the Distributed Profit Taxation Regime of Estonia." Emerging Markets Finance and Trade 45, no. 4: 4-12.

Hovakimian, A., and G. Li. 2011. "In Search of Conclusive Evidence: How to Test for Adjustment to Target Capital Structure." Journal of Corporate Finance 17: 3344.

Jensen, M. C. 1986. "Agency Costs of Free Cash Flow, Corporate Finance, and Takeovers." American Economic Review 76, no. 2: 323-329.

Kim, W. S., and E. H. Sorensen. 1986. "Evidence on the Impact of the Agency Costs of Debt on Corporate Debt Policy." Journal of Financial and Quantitative Analysis 21, no. 2: 131-144.

Korajczyk, R. A., and A. Levy. 2003. "Capital Structure Choice: Macroeconomic Conditions and Financial Constraints." Journal of Financial Economics 68: 75109.

Kuo, H., and L. Wang. 2005. "The Effect of the Degree of Internationalization on Capital Structure for Listed Multinational Corporations in Taiwan during the Asian Financial Crisis." Review of Pacific Basin Financial Markets and 
Policies 8, no. 3: 447-466.

Levy, A., and C. Hennessy. 2007. "Why Does Capital Structure Choice Vary with Macroeconomic Conditions?" Journal of Monetary Economics 54, no. 6: 15451564.

Miller, M. H. 1977. "Debt and Taxes." Journal of Finance 32, no. 2: 261-275.

Modigliani, F., and M. H. Miller. 1958. "The Cost of Capital, Corporation Finance and the Theory of Investment." American Economic Review 48, no. 3: 261-297.

Nieh, C.; H. Yau; and W. Liu. 2008. "Investigation of Target Capital Structure for Electronic Listed Firms in Taiwan." Emerging Markets Finance and Trade 44, no. 4: 75-87.

Ozkan, A. 2001. "Determinants of Capital Structure and Adjustment to Long Run Target: Evidence from UK Company Panel Data." Journal of Business Finance \& Accounting 28, nos. $1 \& 2: 175-198$.

Qian, Y.; Y. Tian; and T. S. Wirjanto. 2009. "Do Chinese publicly listed companies adjust their capital structure toward a target level?" China Economic Review 20, no. 4: 662-676.

StataCorp. 2009. Stata Longitudinal-Data/Panel-Data Reference Manual Release 11. College Station, TX: StataCorp LP.

Titman, S., and R. Wessels. 1988. "The Determinants of Capital Structure Choice." 
Journal of Finance 43, no. 1: 1-19.

Wald, J. K. 1999. "How Firm Characteristics Affect Capital Structure: An International Comparison." Journal of Financial Research 22, no. 2: 161-187.

Windmeijer, F. 2005. "A finite sample correction for the variance of linear efficient two-step GMM estimators." Journal of Econometrics 126, no. 1: 25-51.

Wiwattanakantang, Y. 1999. "An Empirical Study on the Determinants of the Capital Structure of Thai Firms." Pacific-Basin Finance Journal 7, nos. 3 \& 4: 371-403. 